\title{
PROFILE OF PATIENTS WITH CARPAL TUNNEL SYNDROME TREATED AT A REFERRAL SERVICE
}

\section{PERFIL DE PACIENTES COM SÍNDROME DO TÚNEL DO CARPO ATENDIDOS EM UM SERVIÇO DE REFERÊNCIA}

\author{
Henver Ribeiro de Paiva Filho ${ }^{1}$ (i), Valdênia das Graças Nascimento Paiva ${ }^{1}$ (i), Elias Felix de Oliveira ${ }^{1}$ (i), \\ MURILO ANTONNIO ROCHA ${ }^{1}$ (1)
}

1. Universidade Federal do Triângulo Mineiro, Uberaba, MG, Brazil.

\section{ABSTRACT}

Objective: To describe the clinical and epidemiological characteristics of people diagnosed with carpal tunnel syndrome (CTS) treated at a hand surgery outpatient clinic of a regional referral service. Methods: Interview and specific medical examination of 150 people diagnosed with CTS underwent, and statistical analysis of the results obtained. Results: Women smokers, in the fifth decade of life, married, overweight and educated until the elementary level prevailed in our study. Arterial hypertension and diabetes were the most reported comorbidities, and Durkan's test was the most prevalent. Conclusion: CTS is prevalent in women in their fifth decade of life, with bilateral involvement and high school. The hypertension and diabetes are the most common diseases in people with CTS. Level of evidence IV, Case series.

Keywords: Carpal Tunnel Syndrome. Median Neuropathy. Epidemiology.

\section{RESUMO}

Objetivo: descrever as características clínicas e epidemiológicas das pessoas diagnosticadas com síndrome do túnel carpal (STC) atendidas em um ambulatório de cirurgia da mão de um serviço de referência regional. Métodos: Entrevista e exame médico específico de 150 pessoas diagnosticadas com STC e análise estatística dos resultados obtidos. Resultados: Houve prevalência de mulheres tabagistas, na quinta década de vida, casadas, com nível de instrução até o nível fundamental. Hipertensão arterial sistêmica e diabetes foram as comorbidades mais relatadas e o teste de Durkan foi o mais prevalente. Conclusão: A STC é prevalente em mulheres na quinta década de vida, com acometimento bilateral e nível de escolaridade até o ensino médio. Hipertensão e diabetes são as comorbidades mais frequentes em pessoas com STC. Nível de evidência IV, Série de casos.

Descritores: Síndrome do Túnel Carpal. Neuropatia Mediana. Epidemiologia.

Citation: Paiva Filho HR, Paiva VGN, Oliveira EF, Rocha MA. Profile of patients with carpal tunnel syndrome treated at a referral service. Acta Ortop Bras. [online]. 2020;24(1):117-20. Available from URL: http://www.scielo.br/aob.

\section{INTRODUCTION}

Carpal tunnel syndrome (CTS) is the most common peripheral neuropathy associated with the compression of the median nerve at the level of the carpal tunnel. This syndrome is characterized by numbness, tingling, and, in advanced cases, weakness of the thumb and thenar atrophy. ${ }^{1}$

The median nerve is located below the transverse carpal ligament, and it provides motor and sensory function for the hand. Its delicate positioning makes it susceptible to compression and, in prolonged cases, can lead to compression neuropathy. ${ }^{2}$

The subjects with CTS may describe symptoms in the area of median nerve innervation (thumb, index finger, middle finger and radial side of the ring finger), as well as pain in thenar eminence and, with advanced compression, weakness and atrophy of the abductor pollicis brevis and opponens pollicis muscles. ${ }^{3}$

The overall prevalence ranges between $2.1 \%$ and $3 \%$ of the population. ${ }^{4}$ Risk factors for this condition include pregnancy, fractures, hypothyroidism, rheumatoid arthritis, diabetes, and obesity. ${ }^{5}$

In most cases, CTS is considered idiopathic. Even with the large number of original research on the subject, its etiology and the contribution of work on daily routine as a causal agent of this condition are still controversial. Moreover, its pathophysiology has not been fully clarified. Nerve ischemia by increased pressure within the carpal tunnel, vascular alteration and chronic focal compression deformation are conflicting opinions described in the literature. ${ }^{6}$

All authors declare no potential conflict of interest related to this article. 
This study is justified by the lack of publications in the literature presenting the characteristics of people with CTS attended at a regional referral service of the Brazilian Unified Health System. Our aim is to describe the clinical and epidemiological characteristics of people diagnosed with CTS attended in a hand surgery outpatient clinic of a university hospital.

\section{METHODS}

A cross-sectional observational study of quali-quantitative nature was conducted, presenting as design the assessment of patients admitted consecutively in the period of six months in the hand surgery outpatient clinic of a university hospital. All procedures were performed in accordance with the ethical standards determined both by the Research Ethics Committee for Research in Human Beings (CAAE 17608319.9.0000.8667 and Opinion No. 3,578,491 of 09/16/2019) and by the 1964 Declaration of Helsinki. The Free and Informed Consent Form was obtained from all study participants, upon signature of a specific term.

The inclusion criteria were people of both sexes, over 18 years old, in an initial appointment at the hand surgery outpatient clinic, who presented the clinical diagnosis of CTS written in the medical referral of Primary Health Care. People who presented cognitive or mental alterations that made the interview impossible were excluded, as well as those who did not provide consent to this research.

A total of 150 people met the said criteria and were submitted to interview and specific medical exam, according to the routine of the hand surgery outpatient clinic. To characterize the sample and present the results of data collection, qualitative variables (sex, smoking, marital status, dominance, affected limb, schooling level, and presence of comorbidities) were assessed using absolute and relative frequencies, while quantitative (age and body mass index - BMI) were assessed using average, standard deviation, median, minimum and maximum.

The CTS prevalence was described according to each qualitative characteristic, and the association with the use of chi-square or exact tests (Fisher's exact test or likelihood ratio test) was verified. Quantitative characteristics were described according to CTS and compared with the use of the Student's t-test or Mann-Whitney test.

The IBM-SPSS for Windows version 22.0 was used for the analyses, and the software Microsoft Excel 2003 was used for data tabulation. The tests were performed with $5 \%$ significance level.

\section{RESULTS}

Table 1 describes the personal characteristics and associated diseases in our sample. A total of 150 people with CTS were attended, 120 women (80\%) and 30 men (20\%), with a mean age of $54.1 \pm 10.9$ years. The mean BMI was $27.3 \mathrm{~kg} / \mathrm{m}^{2}$. In total, 105 people (70\%) did not smoke, 25 (16.7\%) reported being former smokers and 20 (13.3\%) claimed to be smokers. Most people declared to be married, corresponding to 96 cases (64\%), followed by 23 singles (15.3\%), 22 divorced (14.7\%) and 9 widow/widowers (6\%). Right hand dominance was reported in 146 people (97.3\%), and left hand dominance in 4 (2.7\%). The occurrence of symptoms in both hands (bilaterally) was reported by 92 people (61.3\%), while 58 (38.7\%) reported having symptoms unilaterally. In relation to schooling, 30 people
(20\%) reported being literate, 79 (52.7\%) had elementary school, 33 (22\%) high school, and 8 (5.3\%) college.

Table 1. Description of the personal characteristics and comorbidities of the patients assessed.

\begin{tabular}{|c|c|}
\hline Variable & Description $(\mathrm{N}=150)$ \\
\hline \multicolumn{2}{|l|}{ Sex, n (\%) } \\
\hline Women & $120(80)$ \\
\hline Men & $30(20)$ \\
\hline \multicolumn{2}{|l|}{ Age (years) } \\
\hline mean SD & 54.110 .9 \\
\hline median (min.; max.) & $53.5(24 ; 79)$ \\
\hline \multicolumn{2}{|c|}{ Body mass index $\left(\mathrm{kg} / \mathrm{m}^{2}\right)$} \\
\hline mean SD & $27.3 \quad 4.5$ \\
\hline median (min.; max.) & $26.2(18.6 ; 44.5)$ \\
\hline \multicolumn{2}{|l|}{ Smoking, $\mathrm{n}(\%)$} \\
\hline No & $105(70)$ \\
\hline Yes & $20(13.3)$ \\
\hline Former smoker & $25(16.7)$ \\
\hline \multicolumn{2}{|l|}{ Marital status, $\mathrm{n}(\%)$} \\
\hline Single & $23(15.3)$ \\
\hline Married & $96(64)$ \\
\hline Divorced & $22(14.7)$ \\
\hline Widow/Widower & $9(6)$ \\
\hline \multicolumn{2}{|l|}{ Dominance, $n(\%)$} \\
\hline Right hand & $146(97.3)$ \\
\hline Left hand & $4(2.7)$ \\
\hline \multicolumn{2}{|l|}{ Occurrence, n (\%) } \\
\hline Unilateral & $58(38.7)$ \\
\hline Bilateral & $92(61.3)$ \\
\hline \multicolumn{2}{|l|}{ Schooling, $n$ (\%) } \\
\hline Literate & $30(20)$ \\
\hline Elementary school & $79(52.7)$ \\
\hline High School & $33(22)$ \\
\hline College & $8(5.3 \%)$ \\
\hline \multicolumn{2}{|c|}{ Number of comorbidities } \\
\hline mean SD & $2.3 \quad 1.7$ \\
\hline median (min.; max.) & $2(0 ; 7)$ \\
\hline \multicolumn{2}{|c|}{ Systemic Arterial Hypertension $\mathrm{n}(\%)$} \\
\hline No & $78(52)$ \\
\hline Yes & $72(48)$ \\
\hline \multicolumn{2}{|l|}{ Diabetes, $\mathbf{n}(\%)$} \\
\hline No & $121(80.7)$ \\
\hline Yes & $29(19.3)$ \\
\hline \multicolumn{2}{|l|}{ Fibromyalgia, $\mathrm{n}(\%)$} \\
\hline No & $107(71.3)$ \\
\hline Yes & $43(28.7)$ \\
\hline
\end{tabular}

The mean value of comorbidities presented was 2.3 per person. Out of these, systemic arterial hypertension (SAH) was observed in 72 cases (48\%), while 78 (52\%) did not present this condition. The presence of diabetes was reported by 29 people (19.3\%), while $121(80.7 \%)$ did not report the disease. A total of 43 people (28.7\%) reported treatment for fibromyalgia, while 107 (71.3\%) did not report the treatment.

Table 2 shows the characteristics of the symptoms mentioned and diagnostic tests applied in our sample. 
Table 2. Description of symptoms and diagnostic tests performed.

\begin{tabular}{|c|c|}
\hline Variable & Description $(\mathrm{N}=150)$ \\
\hline \multicolumn{2}{|l|}{ Pain, n (\%) } \\
\hline No & $21(14)$ \\
\hline Yes & $129(86)$ \\
\hline \multicolumn{2}{|c|}{ Sensitivity alteration, $\mathbf{n}(\%)$} \\
\hline No & $56(37.3 \%)$ \\
\hline Yes & $94(62.7)$ \\
\hline \multicolumn{2}{|l|}{ Loss of strength, $\mathbf{n}(\%)$} \\
\hline No & $53(35.3)$ \\
\hline Yes & $97(64.7)$ \\
\hline \multicolumn{2}{|l|}{ Numbness, $\mathrm{n}(\%)$} \\
\hline No & $14(9.3)$ \\
\hline Yes & $136(90.7)$ \\
\hline \multicolumn{2}{|l|}{ Tinel's sign, $\mathrm{n}(\%)$} \\
\hline Negative & $69(46)$ \\
\hline Positive & $81(54)$ \\
\hline \multicolumn{2}{|c|}{ Phalen's maneuver, $\mathrm{n}(\%)$} \\
\hline Negative & $85(56.7)$ \\
\hline Positive & $65(43.3)$ \\
\hline \multicolumn{2}{|l|}{ Durkan's test, n (\%) } \\
\hline Negative & $66(44)$ \\
\hline Positive & $84(56)$ \\
\hline \multicolumn{2}{|l|}{ Flick sign, $\mathrm{n}(\%)$} \\
\hline Negative & $52(34.7)$ \\
\hline Positive & $98(65.3)$ \\
\hline \multicolumn{2}{|c|}{ Time since diagnosis (years) } \\
\hline mean SD & $4.6 \quad 3.6$ \\
\hline median (min.; max.) & $4(0 ; 18)$ \\
\hline
\end{tabular}

Pain was reported in 129 people (86\%), while 21 (14\%) did not report symptoms with pain. Sensitivity alteration was reported by 94 people (62.7\%) while 56 (37.3\%) did not show this alteration. Regarding loss of strength, 97 people $(64.7 \%)$ reported this symptom and 53 (35.3\%) denied it. Numbness was reported by 136 people (90.7\%), while 14 (9.3\%) did not report this symptom. Tinel's test was positive in 81 people (54\%) and negative in 69 (46\%). Phalen's test was positive in 65 people (43.3\%) and negative in 85 (56.7\%). Finally, the Durkan's test was considered positive in 84 people (56\%) and negative in 66 (44\%). The Flick's sign maneuver was reported by 98 people (65.3\%), while 52 (34.7\%) did not report it. When asked about the time between the onset of symptoms and the search for medical care for CTS diagnosis, the mean value found was 4.6 years.

Table 3 shows the result of the adjusted model to explain the presence of CTS in people according to age and presence of fibromyalgia.

Table 3. Result of the model adjusted to explain the presence of carpal tunnel syndrome in patients according to the characteristics assessed.

\begin{tabular}{c|c|c|c|c}
\hline \multirow{2}{*}{ Variable } & \multirow{2}{*}{ OR } & \multicolumn{2}{|c|}{$\mathbf{( 9 5 \% \mathrm { Cl } )}$} & \multirow{2}{*}{$\mathbf{p}$} \\
\cline { 3 - 4 } & & Inferior & Higher Education & \\
\hline Age (years) & 1.05 & 1.01 & 1.08 & 0.017 \\
\hline Fibromyalgia & 0.34 & 0.16 & 0.73 & 0.006 \\
\hline
\end{tabular}

Multiple logistic regression with Stepwise backward selection method with input and output criterion of $5 \%$.

\section{DISCUSSION}

The carpal tunnel is the channel in which the floor is formed by the carpal bones, and the ceiling is the thick and inelastic transverse carpal ligament. In this tunnel, the median nerve is on the surface of the superficial flexor tendons of the fingers, and any factor that increases the contents within the tunnel can compress the median nerve, leading to symptoms of paresthesia in its innervation area. ${ }^{7}$ CTS is more frequent in women between the fourth and sixth decades of life, although this syndrome can be found in men and in all age groups, including it has been described in children and young people. ${ }^{8}$ Our studies met the literature, with a prevalence of women in $80 \%$ of cases and mean age of 54.1 years.

Shiri et al., ${ }^{9}$ in a meta-analysis, found that overweight and obese people had an increased risk of CTS. Our study also showed a significant number of people with $\mathrm{BMI}$ above normal values. Although no statistical significance was observed, our results can be used to promote healthy habits and activities for the population and prevent worsening.

In some cross-sectional studies, smoking is recognized as a risk factor for CTS; ${ }^{10-12}$ however, studies on its pathophysiology are scarce. In our study, $30 \%$ of people reported smoking or were former smokers. We believe that further investigations can help verify correlations between smoking and the development or worsening of CTS.

Studies by Mattioli et al. ${ }^{13}$ show that marital status may be associated with CTS; however, its results do not clearly justify this correlation, suggesting that individual and labor factors should be investigated to better elucidate this trend. Our study showed prevalence of married people, corresponding to almost twice of those divorced and single combined.

Dominance was also investigated in our study, showing prevalence of right-handed people, but bilateral symptomatology was reported in more than half of the cases.

According to Pourmemari et al. ${ }^{14}$, the prevalence of CTS in people with low education was $60 \%$ higher than in those with a high and higher level of education. For these authors, people with a higher level of education are less at risk of being submitted to decompression surgery of the median nerve at the level of the carpal tunnel compared with low educational level. In our study, more than half of the people also had a lower education level than high school, and none of them had undergone prior surgical procedure.

One of the most common complications of diabetes is peripheral neuropathy, and among focal neuropathies (mononeuritis and compression syndromes), CTS is frequent in diabetic people due to some alteration in the synovial tissue surrounding the nerve and because the nerve presents secondary alteration to high blood glucose. ${ }^{15}$ In our study, there was a prevalence of systemic comorbidities, arterial hypertension and diabetes in more than half of the cases.

The literature indicates the Tinel's (50\% sensitivity and $67 \%$ specificity) and Phalen's tests (75\% sensitivity and $47 \%$ specificity) as the most used in clinical practice for the diagnostic aid of CTS ${ }^{16}$ Nowak and Noszczyk ${ }^{17}$ also report Durkan's and Phalen's tests as the most positive clinical trials in people with CTS. In our results, we found the Durkan's test as the most prevalent, followed by Tinel's and Phalen's, respectively. The Flick's sign maneuver, which consists of shaking hands to relieve symptoms of numbness especially at night, was the most reported, being present in almost two-thirds of people affected by CTS in our sample.

Fibromyalgia is a chronic pain syndrome characterized by generalized involvement and pain to muscle palpation, in addition to fatigue, morning stiffness, non-restorative sleep and cognitive symptoms. ${ }^{18}$ Some studies show that CTS is more common in people with fibromyalgia, ${ }^{19}$ and paresthesia in the extremities is related to abnormal sensory perception due to central sensitization, and this may interfere with the interpretation of paresthetic symptoms in CTS. ${ }^{20}$ In our study, only age and the presence of fibromyalgia influenced the diagnosis of CTS, so that every year of age the chance of CTS increased $5 \%$, regardless of the other characteristics 
assessed. We observed in our study that people with CTS and fibromyalgia presented a statistically higher mean age than those with CTS without fibromyalgia ( $p=0.010$ ). The frequency of CTS in patients with fibromyalgia was statistically lower than in patients without fibromyalgia ( $p=0.003$ ).

The positive finding of our study was the high number of cases, which included most patients treated at secondary level with the diagnosis of CTS in the stipulated period. On the other hand, because our hand surgery service is a regional reference for several surrounding cities, our results may not present the reality of Primary Health Care services. We suggest studies on different levels of health care to better evaluate the profile of the person with CTS

\section{CONCLUSION}

CTS is prevalent in women in the fifth decade of life, with bilateral occurrence and lower level of education. Systemic hypertension and diabetes are the most frequent comorbidities in people with CTS.

AUTHORS' CONTRIBUTIONS: Each author contributed individually and significantly to the development of this article: HRPF: performed bibliographic research and data collection and participated in the discussion of the results; VGNP: idealized the study, checked the results of statistical analysis and the final writing of the manuscript; EFO: assessed the data from statistical analysis; MAR: reviewed the statistical analysis and the final writing of the text.

\section{REFERENCES}

1. Ahn DS. Hand elevation: a new test for carpal tunnel syndrome. Ann Plast Surg. 2001;46(2):120-4.

2. Demino C, Fowler JR. The sensitivity and specificity of nerve conduction studies for diagnosis of carpal tunnel syndrome: a systematic review. Hand (NY). 2019.

3. Mackinnon SE, Novak CB. Compression neuropathies. In: Wolfe SW, Hotchkiss RN, Pederson WC, Kozin SH. Green's operative hand surgery. Amsterdam: Elsevier; 2010. p. 977-1014.

4. Atroshi I, Gummesson C, Johnsson R, Ornstein E, Ranstam J, Rosén I. Prevalence of carpal tunnel syndrome in a general population. JAMA. 1999;282(2):153-8.

5. Violante FS, Farioli A, Graziosi F, Marinelli F, Curti S, Armstrong TJ, et al. Carpal tunnel syndrome and manual work: the OCTOPUS cohort, results of a ten-year longitudinal study. Scand J Work Environ Health. 2016;42(4):280-90.

6. Gelberman RH, Hergenroeder PT, Hargens AR, Lundborg GN, Akeson WH. The carpal tunnel syndrome: a study of carpal canal pressure. J Bone Joint Surg Am. 1981;63(3):380-3

7. Caetano EB. Bases anatômicas e funcionais das cirurgias do membro superior. Rio de Janeiro: Medbook; 2010.

8. Pires PR, Andrade RP. Síndromes compressivas no membro superior. In: Pardini A, Freitas A. Cirurgia da mão: lesões não traumáticas. 2nd ed. Rio de Janeiro: Medbook; 2008. p. 163-9.

9. Shiri R, Pourmemari MH, Falah-Hassani K, Viikari-Juntura E. The effect of excess body mass on the risk of carpal tunnel syndrome: a meta-analysis of 58 studies. Obes Rev. 2015;16(12):1094-104.

10. Riccò M, Signorelli C. Personal and occupational risk factors for carpal tunnel syndrome in meat processing industry workers in Northern Italy. Med Pr. 2017;68(2):199-209.
11. Nathan PA, Keniston RC, Lockwood RS, Meadows KD. Tobacco, caffeine, alcohol, and carpal tunnel syndrome in American industry: a cross-sectional study of 1464 workers. J Occup Environ Med. 1996;38(3):290-8.

12. Tanaka S, Wild DK, Cameron LL, Freund E. Association of occupational and non-occupational risk factors with the prevalence of self-reported carpal tunnel syndrome in a national survey of the working population. Am J Ind Med. 1997;32(5):550-6.

13. Mattioli S, Baldasseroni A, Curti S, Cooke RM, Bena A, de Giacomi G, et al. Incidence rates of in-hospital carpal tunnel syndrome in the general population and possible associations with marital status. BMC Public Health. 2008;8:374

14. Pourmemari MH, Heliövaara M, Viikari-Juntura E, Shiri R. Carpal tunnel release: lifetime prevalence, annual incidence, and risk factors. Muscle Nerve. 2018;58(4):497-502.

15. Marciano LHC, Leite VM, Araújo PMP, Garbino JA. Avaliação do comprometimento neurológico e da prevalência da síndrome do túnel do carpo em pacientes portadores de diabetes mellitus tipo 2. Acta Fisiátr. 2007;14(3):134-41.

16. Li Pi Shan R, Nicolle M, Chan M, Ashworth N, White C, Winston P, et al. Electrodiagnostic testing and treatment for carpal tunnel syndrome in Canada. Can J Neurol Sci. 2016;43(1):178-82.

17. Nowak M, Noszczyk B. Simple clinical tests in severe carpal tunnel syndrome. Pol Przegl Chir. 2012;84(10):502-8.

18. Kim CH, Luedtke CA, Vincent A, Thompson JM, Oh TH. Association of body mass index with symptom severity and quality of life in patients with fibromyalgia. Arthritis Care Res. 2012;64(2):222-8.

19. Nacir B, Genc H, Duyur Cakit B, Karagoz A, Erdem HR. Evaluation of upper extremity nerve conduction velocities and the relationship between fibromyalgia and carpal tunnel syndrome. Arch Med Res. 2012;43(5):369-74.

20. Dyer GSM, Simmons BP. Surgery or nonsurgical therapy for carpal tunnel syndrome? Nat Rev Rheumatol. 2010;6:186-7. 